\title{
A Study on the Effect of a Cooperative Learning Program using a Social Network Service in Education during the COVID-19 Pandemic
}

\author{
Mi Young Jo ${ }^{1}$, Ji Won Park ${ }^{2}$ \\ ${ }^{1}$ Professor, Department of Nursing, Kyung Buk College, Republic of Korea, jjomi97@hanmail.net \\ ${ }^{2}$ Professor, Department of Nursing, Dong-Eui Institute of Technology, Republic of Korea, \\ pjw@dit.ac.kr \\ Corresponding author: Mi Young Jo
}

\begin{abstract}
This study aimed to introduce a cooperative learning program, using a social networking service (KakaoTalk) for a non-credited course, and examine its educational effects. It analyzed 45 academic underachievers (31.02\%) and 24 voluntary participants (16.55\%) who engaged in the program from among 145 students majoring in basic nursing science at the College of Nursing in Y-city. Test scores of the students were collected before and after implementing the six-session program. SPSS WIN 18.0 program was used to analyze the data and determine the means, standard deviation, lowest scores, highest scores, and independent sample t-test. The analysis of the test scores indicates that the implementation of the program improved academic performance significantly, particularly among the students who previously displayed academic underachievement $(\mathrm{t}=3.11, \mathrm{p}=.003)$. Additionally, the results of analyzing the testimonials and collecting survey responses, regarding satisfaction level, were 4.05 points, and showed that the program would be effective in the COVID-19 era, as it is real-time based, makes it easy to share learning content, enables repeated reviews, develops a sense of responsibility through cooperative learning, and promotes diverse perspectives. The study program could make up for the learning deficits that may arise due to the prolonged pandemic and reduce the learning gap.
\end{abstract}

Keywords: COVID-19, SNS, KakaoTalk, Cooperative Learning, Academic Underachievement

\section{Introduction}

The Chinese government first announced the outbreak of an unidentified pneumonia in Wuhan on December 31st, 2019. This was the beginning of a pandemic due to the coronavirus disease (COVID19) that shook the entire world[1]. In March 2020, the World Health Organization (WHO) expressed concern that the COVID-19 pandemic was "becoming a reality." According to WHO, a pandemic is the occurrence of an epidemic following the outbreak of a disease by a mutated virus, which progresses from the stage of human-to-human spread to the community and, following that, to a very wide area, thereby affecting a large number of people[2]. At the end of February 2020, the Korean Council for University Education suggested that member universities should, "proceed with online education instead of in-class education and avoid delaying the start day for classes. They also suggested that participation in online courses and the submission of assignments should be acknowledged as attendance[3][4].

Received: January 18, 2021; 1st Review Result: March 04, 2021; 2nd Review Result: April 21, 2021

Accepted: May 25, 2021 
According to the Korea Association of Private University Presidents, the first semester ended without any face-to-face classes on May 15th, 2020, in 165 (85.5\%) out of 193 private universities. College students who could not attend normal classes began to demand a refund of the tuition early in the school year in 2020. Furthermore, the low quality of online classes has been repeatedly attributed to the limited communication with instructors[5].

The Ministry of Education, therefore, explored strategies to minimize the learning gap by utilizing high-quality online courses and introducing a flexible curriculum to reduce the learning deficit and enhance the quality of online courses extended due to the pandemic[6]. According to the comprehensive plan for the year released on January 26th, 2021 by the Korean Ministry of Education, the restrictions on remote courses have been lifted and quality management measures have been reinforced so that universities can continue online education in 2021 and can begin offering remote courses from March onwards. Furthermore, the provision to increase the remote courses is available, which used to be allowed for only the top $20 \%$ of the college credits for graduation. However, college students who took online courses in 2020 have expressed their concerns rather than anticipation. The National University Student Council Network conducted a survey with 4,446 college students from September 21st to October 4th, 2020, and it was reported that $71 \%$ of the participants were dissatisfied with the quality of education during the pandemic. According to another survey conducted in November 2020 by the National University Student Council Network, $84.3 \%$ of the respondents stated that the tuition for 2021 should be recalculated as it did not reflect the circumstances of online education[7]. Consequently, it is imperative to establish a strategy to improve the quality of online college courses and reduce learning deficits. According to previous studies on education during the COVID-19 pandemic, the biggest advantage of online education is the reduction of risk from exposure to the infectious disease, and that education can be task-oriented by using various media tools[8]. Furthermore, in terms of convenience and efficiency, online classes have many merits; however, there are numerous issues associated with the quality of instruction[9].

In the 2021 work progress report, the Ministry of Education highlighted the concern arising from the increased gap in academic performance, and educators and politicians predicted that the changed educational environment would lead to discrepancies in academic performance among students[10]. In fact, a news report on research findings that long-term remote education can lead to an increased gap in academic performance alerted the education authorities. Based on this concern, the Korean government has ordered education authorities to reconsider the implementation of traditional offline education starting in the new semester in 2021. Currently, authorities are examining strategies that could reduce the gap in academic performance that occurred during this period[11]. As the pandemic has not ended yet, news media platforms have reported that the first college semester of 2021 will also adopt the online education model to avoid the risk of spreading the infection[12]. However, it is imperative to find solutions to address the gap in academic performance and the learning deficit. For this purpose, studies on how to address the inadequacy of online classes have been conducted. The main tasks for the future entail the development of customized teaching material suitable for online education and it is imperative to develop content that can be used for online classes[13].

The year 2020 was unusual due to the COVID-19 pandemic. During this unprecedented year, online education had to be implemented for all students from elementary schools to colleges. Under these circumstances, colleges have been working to improve the quality of online education and to reduce the gap in academic achievement among students. This study implements a cooperative learning program for a non-credited course, using KakaoTalk, a Social Network Service (SNS), and analyzes the educational effect of the program. It intends to develop various teaching methods and programs with diverse support for improving the academic performance of students with poor learning skills. While there is a continued impact on college education due to the pandemic, this study explores the educational implications by assuming that the learning deficit and gap arising from the prolonged pandemic can be 
addressed by implementing this program for online education in the COVID-19 era. The research questions that this study aims to answer are:

- What are the advantages of teaching programs that use the SNS app KakaoTalk?

- What are the outcomes of implementing cooperative learning?

- What are the effects of the program on education during the COVID-19 era?

\section{Theoretical Background}

\subsection{Educational Effect of SNS}

Users can form personal networks on the Internet by using SNSs. These are a medium of two-way communication and help people share information with others or form social relationships for a particular purpose[14]. This has become a crucial channel for communication and information collection, as it provides a platform for online communities. Therefore, these sites play a key role as a medium to communicate to countries across the world[15].

Studies on the educational efficiency of using SNSs have indicated an improvement in academic performance in most cases. The educational potential and effect of using these sites have been verified[16], and improvement in academic participation has also been observed[17]. In cooperative learning, it has been found that reflective activities using SNSs exert a positive effect on learning flow and academic achievement[18]. By encouraging mutual cooperation among the community, SNSs amplify the effect of collective intelligence and develop professionalism[19]. In cooperative learning, SNSs can be used as a supplemental learning tool based on communication and collaboration[20]. Various effects, such as an increase in interaction among learners, as well as the instructional media attributes of SNSs for sharing knowledge, have been observed[21-23].

SNSs were not originally developed for sharing educational content but can be utilized to create personal or shared spaces, such as knowledge communities. When self-oriented activities are simultaneously performed with social interaction, learners show improvement in self-directed learning (which refers to the planning and execution by learners themselves), academic performance, and selfefficacy in information technology (which is manifested in learning satisfaction)[24]. Therefore, empirical application to actual college education has significance and educational value for learning, based on the finding that college courses that use SNSs can positively affect learners' attitudes, selfefficacy, and learning presence[25].

\subsection{Educational Effect of Cooperative Learning}

Cooperative learning promotes positive and active interaction among learners and positively affects their attitude and interest toward learning, which ultimately leads to improved academic performance. Additionally, learners who carry out tasks in collaboration with others can interpret a given situation in separate ways, and therefore their problem-solving abilities and their thought processes improve. In other words, collaborative learning provides interaction and its positive effect in the affective domain promotes learning activities[26].

As a medium of learning, SNSs have a potentially positive function in improving the impact of instruction. The development of such sites increases the feasibility of building social knowledge[27][28] and allows users to form an online community to share information and engage in collaborative activities. As such, SNSs are being rapidly adopted in business and daily life, and their scope is expanding[29]. As these offer a platform for sharing information and opinions, they can assist in building a positive attitude when applied to cooperative learning[30]. Cooperative learning using SNSs can assist in forming an interactive community that promotes sharing of opinions and information among learners. 
Therefore, when used for cooperative learning, these can have a positive impact on academic achievement[31][32]. Studies have verified the direct and significant educational impact of cooperative learning[33], and the specific learning effect of collaborative knowledge building on the improvement in academic achievement has also been analyzed[34].

In this study, KakaoTalk, a real-time interaction SNS app that is commonly used in South Korea, has been used to implement an educational program through six sessions. The study examines the educational value of using an SNS platform to share opinions and information and to build knowledge among members in cooperative learning. As cooperative learning is based on mutual collaboration, analyzing the learning effect has implications that are similar to the analysis of students' opinions about the process.

\subsection{Academic Underachievement in College Education}

The concept of academic underachievement can vary depending on the researcher's perspective. Three types of underachievers are taken into consideration while defining academic achievement. The first type has the intelligence to learn but fails to fully demonstrate their potential. The second type is unable to achieve the minimum standards required in certain areas. Unlike the first and second types, the third type of underachiever has a learning disability, identified through an intelligence or learning disability test[35].

A lack of basic learning competencies in students with severe learning deficits has been investigated as a crucial factor for colleges. Students lacking basic learning competencies and those who are unprepared for college education are accepted to colleges more readily now than in the past, as college education has become common and the number of students seeking admission is below the capacity. In the case of community (or junior) colleges, there has been an increase in the number of students who fail to adjust to college life and drop out or give up studies because of poor academic performance. This has led to discussions on strategies to improve basic learning competencies. Academic underachievement of students leads to an academic warning, affecting their ability to adjust to college life, and they eventually drop out of college. According to a study that compared the attributes of college students on academic probation with those who have exceptional academic performance, the former students were found to have lower levels of satisfaction with college, the classes, and their major, as compared to the latter. They also invested less effort and time in studying[36-38]. Another study that analyzed academic underachievers stated that the factors behind academic underachievement include inadequate preparedness for learning, problems with managing time, and lack of self-discipline and motivation. An additional factor that was identified in another study was the absence of proper learning skills[39]. Some studies categorized the factors that led to academic underachievement into external and internal factors pertaining to individual students. Internal factors include the absence of a learning strategy, lack of motivation to learn, unmatched aptitude, and poor mental health. External factors include inadequate learning environment, maladjustment to instructional methods and curriculum, and low participation in the student body. Researchers have proposed the following strategies to address underachievement: providing a supplementary learning program, increasing feedback from instructors, and renewing students' motivation[40].

As a concept that assumes that the full potential has not been realized, academic underachievement acknowledges students' competences and their ability to overcome challenges. To address academic underachievement, the main focus in college education should be on enhancing the competence that has not been demonstrated during learning activities. As the level of academic achievement in college education is not determined by the students' competence independently, it is necessary for colleges to offer multilateral support to improve academic achievement and develop a long-term and diverse instructional strategy and program to ensure continued academic achievement, as opposed to operating 
short-term and temporary educational programs for new students.

\section{Research Method}

\subsection{Development of Cooperative Learning Program using an SNS App, KakaoTalk}

A program using KakaoTalk was developed after reviewing previous studies and literature. Four topics that were difficult to comprehend without assistance were selected from a pathology textbook. Following that, two professors, each from the field of education and nursing science, were consulted. The validity of the topics and the suitability for cooperative learning were surveyed on a 4-point Likert scale and were found to be at 3.2. The advisors agreed that the topics selected would be appropriate for cooperative learning as they require memorization and review. After implementing the developed program in six sessions, a survey was conducted with the participants to comprehend their satisfaction with the program, and they were requested to share testimonials. Based on the survey and the testimonials, the final program, as shown in [Table 1], has been developed.

[Table 1] Process of Developing the Non-credited Course Program using an SNS

\begin{tabular}{|c|c|c|}
\hline Procedure & \multicolumn{2}{|r|}{ Content } \\
\hline $\begin{array}{l}\text { Review previous } \\
\text { studies }\end{array}$ & \multicolumn{2}{|r|}{ Examine previous studies and literature } \\
\hline Design program & \multicolumn{2}{|r|}{ Design a cooperative learning program using the SNS app, KakaoTalk } \\
\hline Consult with experts & \multicolumn{2}{|c|}{ Consult four experts: two professors of education and two professors of nursing science } \\
\hline Give instructions & \multicolumn{2}{|r|}{ Give each group program-related instructions } \\
\hline \multirow{9}{*}{$\begin{array}{l}\text { Implement the } \\
\text { program }\end{array}$} & \multicolumn{2}{|r|}{ Give a weekly notice prior to the program } \\
\hline & & $\sqrt{8}$ \\
\hline & & Share motivation and strategies for studying \\
\hline & & $\sqrt{ }$ \\
\hline & Review the & $\begin{array}{l}\text { ited course; create multiple-choice questions and submit these to the instructor via } \\
\text { email; receive feedback }\end{array}$ \\
\hline & & 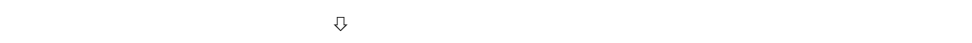 \\
\hline & At this & $\begin{array}{l}\text { course, engage in cooperative learning by sharing the created questions and by } \\
\text { checking the answers online via KakaoTalk }\end{array}$ \\
\hline & & $\checkmark$ \\
\hline & & Share feedback on the created questions \\
\hline \multirow{4}{*}{$\begin{array}{c}\text { Content of program } \\
\text { for each } \\
\text { session }\end{array}$} & Session 1 & $\begin{array}{c}\cdot \text { Present the learning strategy- motivation, setting goals } \\
\cdot \text { Content to study- viral diseases }\end{array}$ \\
\hline & Session 2 & $\begin{array}{l}\cdot \text { Present the learning strategy-summarization, memorization } \\
\cdot \text { Content to study-congenital disorders }\end{array}$ \\
\hline & Session 3 & $\begin{array}{l}\text { - Present the learning strategy- writing a study plan, time management } \\
\cdot \text { Content to study- benign tumors }\end{array}$ \\
\hline & Session 4 & $\begin{array}{l}\cdot \text { Present the learning strategy-textbook utilization, test-taking strategy } \\
\cdot \text { Content to study- malignant tumors (cancers) }\end{array}$ \\
\hline Evaluate & Session 5 & Administer a test using the questions created in previous sessions \\
\hline \multirow{2}{*}{$\begin{array}{l}\text { Give final } \\
\text { feedback }\end{array}$} & Session 6 & $\begin{array}{c}\text { Share the developed questions for review prior to the final exam } \\
\text { and give final feedback }\end{array}$ \\
\hline & \multicolumn{2}{|c|}{ Identify and award students with exceptional scores and the students who developed excellent questions } \\
\hline
\end{tabular}


A Study on the Effect of a Cooperative Learning Program using a Social Network Service in Education during the COVID-19

\begin{tabular}{|c|c|}
\hline $\begin{array}{c}\text { Analyze the } \\
\text { improvement in } \\
\text { learning competence }\end{array}$ & Analyze the scores before and after the implementation of the cooperative learning program using \\
KakaoTalk
\end{tabular}

\subsection{Verifying the Effect of the Cooperative Learning Program using an SNS App, KakaoTalk}

\subsubsection{Research Design}

This research employed a one-group pretest-posttest design, which is a quasi-experimental design, to verify the effect of a cooperative learning program using KakaoTalk.

\subsubsection{Research Participants}

A total of 69 students, including several academic underachievers, were selected from 145 students enrolled for the pathology course, which is a mandatory course for nursing major students at the College of Nursing, Y-city. Of these participants, 45 academic underachievers (31.02\%) were mandatory participants in the program and selected based on the rank percentage (51\% and up) in the midterm exam. A research analysis was conducted with these students and 24 voluntary participants $(16.55 \%)$. The rank percentage of the research participants is as shown in [Table 2].

[Table 2] Composition of Research Participants by Rank Percentage

\begin{tabular}{|c|c|c|c|c|c|}
\hline \multirow{2}{*}{ Group } & \multirow{2}{*}{ Rank percentage $(\%)$} & \multicolumn{2}{|c|}{ Students $(\mathrm{N})$} & \multirow{2}{*}{\multicolumn{2}{|c|}{ Percentage (\%) }} \\
\hline & & Male & Female & & \\
\hline \multirow{5}{*}{$\begin{array}{l}\text { Voluntary participants } \\
\text { in the program }\end{array}$} & $1-10$ & 1 & 5 & 4.14 & \multirow{5}{*}{16.55} \\
\hline & $11-20$ & 0 & 1 & 0.69 & \\
\hline & $21-30$ & 2 & 7 & 6.02 & \\
\hline & $31-40$ & 0 & 8 & 5.52 & \\
\hline & $41-50$ & 0 & 0 & 0 & \\
\hline \multirow{5}{*}{$\begin{array}{l}\text { Mandatory } \\
\text { participants in the } \\
\text { program }\end{array}$} & $51-60$ & 1 & 5 & 4.14 & \multirow{5}{*}{31.02} \\
\hline & $61-70$ & 1 & 8 & 6.20 & \\
\hline & $71-80$ & 1 & 8 & 6.20 & \\
\hline & $81-90$ & 0 & 9 & 6.20 & \\
\hline & $91-100$ & 3 & 9 & 8.28 & \\
\hline Total & & \multicolumn{2}{|c|}{69} & \multicolumn{2}{|c|}{47.57} \\
\hline
\end{tabular}

\subsubsection{Ethical Considerations}

Prior to the implementation of the program, the purpose of the study was explained to the participants, and they were assured that the survey and individual interview materials would be used only for the purpose of analysis in this study. For the ethical protection of the study subjects, they were informed that participation in online questionnaires and individual interviews could be autonomously determined, and the anonymity of the students was guaranteed. 


\subsubsection{Research Tool}

\subsubsection{Experimental Tool: Cooperative Learning Program using KakaoTalk}

The experimental tool in this research is a cooperative learning program implemented by using KakaoTalk as the platform. The experiment was conducted over six sessions of sixty-minutes each. At the beginning of the program development, previous studies and literature related to cooperative learning, academic underachievement, and the use of SNSs for educational purposes were reviewed. After designing the program, detailed instructions on the program and each participant's role and responsibility in cooperative learning were provided before the first session. At this stage, the instructor motivated the students to engage in self-directed learning and presented the learning goals while informing them about the educational effect of cooperative learning and their responsibilities. The content of each session was as follows.

In session 1, strategies of self-motivation and goal setting were presented. Students were instructed to review the regular course material on viral diseases, create 10 multiple-choice questions, and email the questions to the instructor during cooperative learning. The instructor corrected any errors in the questions and provided time for questions and answers to ensure that the students did not develop any misconceptions while creating questions. After the questions were checked by the instructor, cooperative learning using KakaoTalk was conducted in each group at the agreed-upon time. When a student's name was called out in the group chat room, the set of questions he or she created were shared with the rest of the students and they were answered. Students took turns to share the developed questions, and other students answered the shared questions. At the end, the correct answers were given, and the students exchanged questions and answered in real time as a way of reviewing the week's content.

In session 2, strategies for summarizing and memorizing were shared. Students reviewed the regular course material on congenital disorders and proceeded with the program in the same manner as during the first session.

In session 3, strategies for writing study plans and managing time were shared. Students reviewed the regular course material on benign tumors and proceeded with the program in the same manner as the previous sessions.

In session 4, strategies for utilizing the textbook and taking tests were shared. Students reviewed the regular course material for malignant tumors. Session 4 also proceeded in the same manner as the previous sessions.

In session 5, by using the questions that the students developed during the program, an interim test was held to give the students an opportunity to assess what they had learned. To motivate the students and improve their satisfaction with learning, the students who demonstrated exceptional scores and developed excellent questions were identified and awarded.

In the last session, all the questions that were developed during cooperative learning were shared with the students. The program concluded with a final feedback session as a review to prepare for the final semester exam. After the sixth session, the marks scored before and after the program were analyzed. The participants' responses regarding the impact of the program were collected and analyzed.

\subsubsection{Measurement Tool}

The test scores, satisfaction with the program, and testimonials have been used as measurement tools. The questions regarding the educational effects of the program are shown in [Table 3]. The testimonials were collated by using open-ended questions to identify the effects of the program. The content of the questions was prepared based on the advice of the professors of education and nursing science. 
A Study on the Effect of a Cooperative Learning Program using a Social Network Service in Education during the COVID-19 Pandemic

[Table 3] Questions about Educational Effect of the Cooperative Learning Program using KakaoTalk

\begin{tabular}{|c|c|c|c|}
\hline Items & $\begin{array}{l}\text { Question } \\
\text { number }\end{array}$ & Content of the question & Question type \\
\hline $\begin{array}{l}\text { General } \\
\text { information }\end{array}$ & & - Gender & Short answer type \\
\hline \multirow{3}{*}{ Score } & & Score in the midterm exam & Short answer type \\
\hline & & - Score in the final exam & Short answer type \\
\hline & & - Final exam score - midterm exam score & Short answer type \\
\hline \multirow{15}{*}{$\begin{array}{l}\text { Satisfaction } \\
\text { (A) }\end{array}$} & A1 & - The program was satisfying. & 5-point Likert scale \\
\hline & $\mathrm{A} 2$ & - The program was effective as an instructional method. & 5-point Likert scale \\
\hline & $\mathrm{A} 3$ & - The program was helpful in improving academic performance. & 5-point Likert scale \\
\hline & A4 & - The program met my expectations. & 5-point Likert scale \\
\hline & A5 & - Collaborative learning is more effective than studying alone. & 5-point Likert scale \\
\hline & A6 & - The duration and frequency of the program were adequate. & 5-point Likert scale \\
\hline & A7 & $\begin{array}{c}\text { - The program helped achieve some goals (i.e., improvement in } \\
\text { learning competence). }\end{array}$ & 5-point Likert scale \\
\hline & A8 & $\begin{array}{l}\text { - The group members helped in improving academic } \\
\text { performance. }\end{array}$ & 5-point Likert scale \\
\hline & A9 & $\begin{array}{c}\text { The group members eagerly participated in collaborative } \\
\text { learning. }\end{array}$ & 5-point Likert scale \\
\hline & A10 & $\begin{array}{l}\text { - I am interested in participating in the program in the next } \\
\text { semester. }\end{array}$ & 5-point Likert scale \\
\hline & A11 & - The members were punctual while participating in the study. & 5-point Likert scale \\
\hline & A12 & $\begin{array}{c}\text { The members did a thorough job in reviewing, previewing, and } \\
\text { creating questions. }\end{array}$ & 5-point Likert scale \\
\hline & A13 & I actively participated during the online assessment. & 5-point Likert scale \\
\hline & A14 & - The members collaborated well with each other. & 5-point Likert scale \\
\hline & A15 & - I faithfully participated in the program. & 5-point Likert scale \\
\hline \multirow{3}{*}{$\begin{array}{c}\text { Testimonials } \\
\text { (B) }\end{array}$} & B1 & $\begin{array}{c}\text { - How do you feel about the program? (overall emotive } \\
\text { response) }\end{array}$ & Essay question \\
\hline & B2 & $\begin{array}{l}\text {-What was the most challenging part about the program? What } \\
\text { requires improvement? (negative experience) }\end{array}$ & Essay question \\
\hline & B3 & $\begin{array}{l}\text { - What was the most effective or the most rewarding part about } \\
\text { the program? What can be applied more in other areas? (positive } \\
\text { experience) }\end{array}$ & Essay question \\
\hline
\end{tabular}

\subsubsection{Method of Data Analysis}

The collected data were analyzed using IBM SPSS Korea and Data Solution Inc. (version 18.0) for Windows. The measurements from the pre-test and post-test were analyzed by taking into consideration the means, standard deviation, lowest scores, highest scores, and independent sample t-tests. The content of the testimonials was also analyzed.

\section{Research Results}

To examine the educational impact of the cooperative learning program using KakaoTalk during the COVID-19 pandemic, first, the differences in scores of the groups before and after implementing the program were analyzed. The analysis of the test scores indicates that the implementation of the program improved academic performance significantly, particularly among the students who previously displayed academic underachievement. Second, the satisfaction of the participants with the program was investigated through a survey. Third, the recorded testimonials about the effect of the program collated 
through interviews with individual participants were analyzed. Further, the result that emerged from analyzing the testimonials and survey responses on the satisfaction level was 4.05 points. It showed that the program is effective in the COVID-19 era mainly because its learning content is easy to share, it is based on real time, enables repeated reviews, develops a sense of responsibility through cooperative learning, and promotes diverse perspectives.

\subsection{Scores before and after Implementing the Cooperative Learning Program}

Each group's scores from the midterm and final exams are shown in [Table 4]. In the academic underachievers group, the mean of midterm exam scores was $24.78 \pm 4.04$ and the mean of the final exam scores was $29.44 \pm 3.45$. In the group of volunteers, the mean of the midterm exam scores was $31.41 \pm 1.44$ and the mean of the final exam scores was $33.23 \pm 2.74$.

The differences between the two groups in the scores from the midterm and final exams are shown in [Table 5]. In the academic underachievers group, the mean of improved scores from the midterm exam was $4.67 \pm 3.53$. In the group of volunteers, the mean of improved scores from the midterm exam was $1.82 \pm 3.13$. The analysis indicates a statistically significant difference between the two groups in terms of the mean of improved scores $(\mathrm{t}=3.11, \mathrm{p}=.003)$.

[Table 4] Scores before and after Implementing the Cooperative Learning Program ( $\mathrm{n}=69)$

\begin{tabular}{|c|c|c|c|c|c|}
\hline & Group (n) & Mean & $\begin{array}{c}\text { Standard } \\
\text { deviation }\end{array}$ & Lowest score & Highest score \\
\hline \multirow{2}{*}{$\begin{array}{c}\text { Midterm } \\
\text { exam } \\
\text { score }\end{array}$} & $\begin{array}{c}\text { Academic } \\
\text { underachievers (45)a }\end{array}$ & 24.78 & 4.04 & 15 & 29 \\
\cline { 2 - 6 } & Volunteers (24)b & 31.41 & 1.44 & 30 & 34 \\
\hline \multirow{2}{*}{$\begin{array}{c}\text { Final exam } \\
\text { score }\end{array}$} & $\begin{array}{c}\text { Academic } \\
\text { underachievers (45)a }\end{array}$ & 29.44 & 3.45 & 20 & 35 \\
\cline { 2 - 6 } & Volunteers (24)b & 33.23 & 2.74 & 25 & 35 \\
\hline
\end{tabular}

[Table 5] Comparison of Score Differences before and after Implementing the Cooperative Learning Program

\begin{tabular}{|c|c|c|c|c|c|c|c|}
\hline & Group (n) & Mean & $\begin{array}{c}\text { Standard } \\
\text { deviation }\end{array}$ & $\begin{array}{c}\text { Lowest } \\
\text { score }\end{array}$ & $\begin{array}{c}\text { Highest } \\
\text { score }\end{array}$ & $\mathrm{t}$ & $p$ \\
\hline $\begin{array}{c}\text { Improved } \\
\text { scores from } \\
\text { midterm } \\
\text { exam }\end{array}$ & $\begin{array}{c}\text { Academic } \\
\text { underachievers (45)a }\end{array}$ & 4.67 & 3.53 & -2 & 12 & & \\
\cline { 2 - 9 } & Volunteers (24)b & 1.82 & 3.13 & -7 & 8 & \multirow{2}{*}{3.11} & $.003 *$ \\
\hline$* p<.001$
\end{tabular}

\subsection{Satisfaction with the Cooperative Learning Program}

The overall satisfaction with the program was 4.05 points and the satisfaction with each question is shown in [Table 6]. The highest level of satisfaction with the program was 4.32 points for item A11 ("The members were punctual in participating in the study.") The second highest satisfaction level was 4.17 points for A1 ("The program was satisfying.") and A2 ("The program was effective as an instructional method."). The lowest satisfaction level was 3.90 points for A4 ("The program met my expectations.") and A14 ("The members collaborated well with each other.") The next lowest satisfaction score (3.91) was for A12 ("The members did a thorough job in reviewing, previewing, and 
A Study on the Effect of a Cooperative Learning Program using a Social Network Service in Education during the COVID-19 Pandemic

creating questions.").

[Table 6] Satisfaction with Cooperative Learning Program using an SNS

\begin{tabular}{|c|c|c|c|c|c|c|c|c|}
\hline & A1 & $\mathrm{A} 2$ & A3 & A4 & A5 & A6 & A7 & A8 \\
\hline Levels & $\begin{array}{c}\text { frequency } \\
(\%)\end{array}$ & $\begin{array}{c}\text { frequency } \\
(\%)\end{array}$ & $\begin{array}{c}\text { frequency } \\
(\%)\end{array}$ & $\begin{array}{c}\text { frequency } \\
(\%)\end{array}$ & $\begin{array}{c}\text { frequency } \\
(\%)\end{array}$ & $\begin{array}{c}\text { frequency } \\
(\%)\end{array}$ & $\begin{array}{c}\text { frequency } \\
(\%)\end{array}$ & frequency $(\%)$ \\
\hline $\begin{array}{c}\text { Very } \\
\text { satisfied } \\
(5)\end{array}$ & 21(30.4) & 21(30.4) & $16(23.2)$ & $14(20.3)$ & $15(21.7)$ & $13(18.8)$ & 13(18.8) & $18(26.1)$ \\
\hline $\begin{array}{c}\text { Satisfied } \\
\text { (4) }\end{array}$ & $39(56.5)$ & $39(56.5)$ & $42(60.9)$ & $38(55.1)$ & $37(53.6)$ & $42(60.9)$ & $45(65.2)$ & $41(59.4)$ \\
\hline $\begin{array}{c}\text { Neither } \\
\text { satisfied } \\
\text { nor } \\
\text { dissatisfi } \\
\text { ed } \\
\text { (3) }\end{array}$ & $9(13.1)$ & $9(13.1)$ & $9(13.0)$ & 13(18.8) & $16(23.2)$ & $14(20.3)$ & $9(13.1)$ & $8(11.6)$ \\
\hline $\begin{array}{c}\text { Dissatisf } \\
\text { ied } \\
\text { (2) }\end{array}$ & $0(0)$ & $0(0)$ & $2(2.9)$ & $4(5.8)$ & $1(1.4)$ & $0(0)$ & $2(2.9)$ & $1(1.4)$ \\
\hline $\begin{array}{c}\text { Very } \\
\text { dissatisfi } \\
\text { ed } \\
\text { (1) }\end{array}$ & $0(0)$ & $0(0)$ & $0(0)$ & $0(0)$ & $0(0)$ & $0(0)$ & $0(0)$ & $1(1.4)$ \\
\hline \multirow[t]{2}{*}{$\begin{array}{c}\text { Sum } \\
\text { (mean) }\end{array}$} & $69(4.17)$ & $69(4.17)$ & $69(4.04)$ & $69(3.90)$ & $69(3.96)$ & $69(3.99)$ & $69(4.00)$ & $69(4.07)$ \\
\hline & A9 & $\mathrm{A} 10$ & A11 & $\mathrm{A} 12$ & $\mathrm{~A} 13$ & A14 & A15 & \multirow{7}{*}{$\begin{array}{l}\text { Total } \\
\text { mean }\end{array}$} \\
\hline Levels & $\begin{array}{c}\text { frequency } \\
(\%)\end{array}$ & $\begin{array}{c}\text { frequency } \\
(\%)\end{array}$ & $\begin{array}{c}\text { frequency } \\
(\%)\end{array}$ & $\begin{array}{c}\text { frequency } \\
(\%)\end{array}$ & $\begin{array}{c}\text { frequency } \\
(\%)\end{array}$ & $\begin{array}{c}\text { frequency } \\
(\%)\end{array}$ & $\begin{array}{c}\text { frequency } \\
(\%)\end{array}$ & \\
\hline $\begin{array}{c}\text { Very } \\
\text { satisfied } \\
(5)\end{array}$ & $14(20.3)$ & $19(27.5)$ & $27(39.1)$ & $16(23.2)$ & $20(29.0)$ & $12(17.4)$ & $19(27.5)$ & \\
\hline $\begin{array}{c}\text { Satisfied } \\
\text { (4) }\end{array}$ & $44(63.8)$ & $37(53.6)$ & $37(53.6)$ & $34(49.3)$ & $37(53.6)$ & $41(59.4)$ & $35(50.7)$ & \\
\hline $\begin{array}{c}\text { Neither } \\
\text { satisfied } \\
\text { nor } \\
\text { dissatisfi } \\
\text { ed } \\
\text { (3) }\end{array}$ & $11(15.9)$ & 11(15.9) & $5(7.2)$ & $16(23.2)$ & $12(17.4)$ & $14(20.3)$ & $13(18.8)$ & \\
\hline $\begin{array}{c}\text { Dissatisf } \\
\text { ied } \\
(2)\end{array}$ & $0(0)$ & $2(2.9)$ & $0(0)$ & $3(4.3)$ & $0(0)$ & $1(1.4)$ & $2(2.9)$ & \\
\hline $\begin{array}{c}\text { Very } \\
\text { dissatisfi } \\
\text { ed } \\
\text { (1) }\end{array}$ & $0(0)$ & $0(0)$ & $0(0)$ & $0(0)$ & $0(0)$ & $1(1.4)$ & $0(0)$ & \\
\hline $\begin{array}{c}\text { Sum } \\
\text { (mean) }\end{array}$ & $69(4.04)$ & $69(4.06)$ & $69(4.32)$ & $69(3.91)$ & $69(4.12)$ & $69(3.90)$ & $69(4.03)$ & 4.05 \\
\hline
\end{tabular}

\subsection{Opinions about the Effect of the Cooperative Learning Program}

After sorting data pertaining to the research goal, eight students were selected from the group of academic underachievers, based on the following criteria: scored a minimum of 32 points in the final exam and displayed maximum improvement from the midterm exam. Interviews with individual participants regarding the effects of the program were recorded and the testimonials were analyzed. To understand the educational effect of the program, the interview included the following topics: "the 
effectiveness and the merit of the program"; "challenging part about the program and areas that require improvement"; and "opinion about using SNSs for education."

The students' opinions can be summarized as follows. First, the respondents mentioned the convenience of cooperative learning through KakaoTalk, as it has no constraints of time or space, enabling real-time group study. Second, the respondents acknowledged the educational impact of repetition as they had to review the study materials to create questions and answer questions created by other students. Third, the analysis of the testimonials indicated that the respondents felt ambivalent about the program because some students demonstrated a lack of interest, while cooperative learning encouraged the formation of diverse opinions and the development of a faithful and sincere attitude.

\subsubsection{Convenience of Learning via SNS (KakaoTalk): Real-time Access and Ease of Sharing Study Material}

Students mentioned the convenience of studying using an SNS as it did not have any constraints of time and space. Connecting to an SNS at the agreed-upon time was considered convenient as it did not require meeting at a physical place, and the ease of sharing the study material was also considered to be an advantage.

Student A

"We could meet at the exact time that we all agreed upon."

"As we all have mobile phones, we could participate from wherever we were, without having to meet in person."

Student B

"SNS freed me from the constraints of time and space."

Student D

"It was convenient and better than meeting in person."

Student $\mathrm{H}$

"Communicating via SNS seemed effective because it is difficult to decide on a time that is convenient for everyone."

"If I have any questions, I can always post them online later..."

\subsubsection{Educational Effect of Repetition}

Students mentioned the benefit of repetition as an effect of the program. They stated that the program helped in improving the scores as they had to review the regular course material to create questions and repeat the process while answering the questions created by other students and when preparing for the final exam.

Student D

"Creating questions every week helped me to review the content naturally."

Student $\mathrm{F}$

"Creating questions first gave me the opportunity to study the content, answering the questions created by others gave me the second opportunity, and overviewing all the questions to prepare for the final exam gave me the third opportunity to study the content."

Student $\mathrm{G}$

"Without realizing, I was getting used to studying and reviewing the content as I created the questions."

"I was glad to learn how to review through the repetition."

Student $\mathrm{H}$

"The printed materials that I would normally glance at only once were reviewed two or three times."

"This program helped me realize that test scores are an honest representation of the amount of effort 
I put in."

\subsubsection{Formation of Diverse Perspectives}

Students mentioned the formation of diverse perspectives as an effect of the program. As a merit of cooperative learning, participants reported that the process of creating and answering questions based on the regular course materials from a variety of perspectives helped them widen their horizon as opposed to the biased views that they originally had.

\section{Student A}

"Even the same questions could be approached from a different perspective, so it was helpful to identify the areas that I had overlooked."

Student B

"I am glad that I learned that each classmate has his or her style of creating questions, and that even the same theory can be interpreted differently."

\section{Student E}

"It was very helpful to learn the aspects that I had not thought about."

\subsubsection{Ambivalence about Cooperative Learning}

Some students complained about the difficulties faced during cooperative learning. While the participants could develop a sense of duty, responsibility, and sincerity through cooperative learning, they had negative feelings toward certain classmates who were getting a free ride during the group study. Additionally, they reported that they were uncomfortable while competing and did not like being compared with peers while answering questions.

\section{Student B}

"When I saw some classmates who were getting a free ride during the group study, I was not very happy."

"When creating the questions, I did it responsibly, keeping in mind that I have to share these with others."

Student C

"As I had to share my questions on the SNS, I did my part with a sense of duty and responsibility." Student E

"Having the opportunity to share the questions that I created gave me the motivation to study."

"As I could not skip the program, I participated in it responsibly. That is how I could participate till the end."

"I was afraid that my answer could be wrong, so I checked my answers against those of my classmates."

Student $\mathrm{H}$

"There were some classmates who were trying to get by with an insincere attitude of 'I don't care."

\section{Discussion and Conclusions}

In this study, a cooperative learning program using an SNS app, KakaoTalk, has been implemented for a non-credited course, and its educational impact has been examined. The study was conducted with the assumption that the implementation of this program could make up for the learning deficits that may arise due to the prolonged pandemic and reduce the learning gap. This program was found to significantly reduce the learning gap among academic underachievers who had a learning deficit in the regular course study. This program has the following implications for education.

First, the academic performance of the students who participated in the program improved. Their 
scores in the final exam improved in comparison with their midterm exam scores. The scores of the academic underachievers increased more significantly than those of the program volunteers who had scored higher in the midterm exam. This indicates that the repeated review of the content exerted a significant educational effect on academic underachievers as they created and shared questions and revised all the questions prior to the final exams. The two groups showed a statistically significant difference in the mean of the improved scores as compared to those in the midterm exam. Meanwhile, for collaborative learning to exert any educational effect, instructors also play a crucial role. According to previous studies, to ensure positive outcomes, the utilization of an SNS should be accompanied by the instructor's assistance and guidance instead of using the platform independently. It was also argued that researchers should be able to objectively analyze SNS content in terms of the quantity and quality of the interaction[41]. To ensure this, the researcher for this study also participated in the KakaoTalk interactions. Students were educated about their responsibility in cooperative learning and were assisted during each session to prevent misconceptions while they engaged in self-directed study to create and answer questions.

Second, the program is a convenient study channel that provides real-time access and facilitates ease of sharing study material through KakaoTalk. The analysis of the satisfaction survey and the testimonials from the interviews with academic underachievers indicated that the use of SNS, which has no restrictions in terms of time and space, had a positive educational effect. Furthermore, students voiced their opinion that SNS is not controlled by time or space and that it is easy to share study material through the platform. They also found it more efficient as they could connect with each other without having to meet in person. Through the program, which is flexible in terms of study space, students can develop time management skills and self-directed learning competence by reviewing and creating questions on their own. This finding supports previous research reporting that the use of SNS in class is associated with learning presence, learning immersion, and learning satisfaction[42]. It also supports previous findings that courses using SNSs can improve student satisfaction and academic achievement when self-oriented activities and social interactions take place simultaneously[43].

Third, the repeated learning activities in the program led to the acquisition of reviewing skills. According to the academic underachievers who participated in the individual interviews, reviewing the regular course content for creating questions, sharing the questions with peers, and going over the questions prior to the final exam helped them to improve their scores, and in the process, they acquired reviewing skills. The method of reviewing through repetition was found to have a positive educational effect on academic underachievers who had difficulty with self-directed learning, as shown in the analysis of the scores before and after implementing the program. Learning deficits can be prevented as underachievers can review the regular course content of the week without delay, by engaging in a cooperative learning program using KakaoTalk. This can assist students who have been facing difficulties in time management and self-directed learning because of prolonged online education. Additionally, the effect was verified in the analysis of the testimonials of academic underachievers whose scores improved greatly. Therefore, this program can help in improving the academic achievement of underachievers.

Fourth, the findings highlight the educational effectiveness of cooperative learning. The sense of responsibility and sincerity of students who participated in the program improved through cooperative learning. Students also realized the importance of their role and duty in collaborative learning. The statement that showed the highest level of satisfaction was "The members were punctual in participating in the study," with 4.32 points. This shows the impact of cooperative learning in improving the sense of responsibility and sincerity as the students tried not to create trouble for their peers during the program. Another benefit was that participants developed diverse views and overcame their biased perspectives.

Finally, cooperative learning had a negative effect on emotional discomfort. Although cooperative learning exerted educational effects, the analysis also showed ambivalence. The participants' 
testimonials revealed that some experienced negative emotions toward students who got a free ride during the program and felt intimidated during the question-and-answer sessions when they competed with their peers. This can be verified in the statement that showed the lowest satisfaction level with 3.90 points was that "The members collaborated well with each other." KakaoTalk and the collaboration within the space encouraged the participation of the members and they influenced each other. However, this study has certain limitations due to the failure to regulate the students who are insincere, and the issue of discomfort during the competition was not resolved. The learners' cooperative learning skills can improve if the instructor promptly monitors the progress of the students to ensure appropriate interaction. Additionally, it is necessary for the instructor to educate the students about the value of collaborative interaction among members in a cooperative learning program.

This study implemented cooperative learning using an SNS app, KakaoTalk, to provide an understanding of the advantages of cooperative learning using SNS in the COVID-19 era. In the process, an improvement in academic achievement was observed and the participants had a strong level of satisfaction with the program which was associated with self-directed learning. Therefore, the outcome or educational effect of implementing the program has been analyzed and it has been established that this is an effective program that can be used in the COVID-19 era. Furthermore, this program can develop a sense of belonging and solidarity in the education field, as it can address the problems arising from studying alone in prolonged online classes, and it highlights the advantages of cooperative learning. If this program is implemented for first-year students who may lack a sense of belonging, as a relationship with their peers has not been established because of online classes, it could prevent dropouts by providing them an opportunity to interact with each other.

Based on the merits of using a platform that enables the formation of a knowledge-based community through active interactions and close communication, this study used KakaoTalk for cooperative learning. The educational effect and improvement in academic performance through cooperative learning have been discussed in this study. However, this study limits the chances of getting a free ride during guidance and heightens competition among students in cooperative learning using SNS. Further, the results are not generalizable to all university students as the participants for this study only included nursing students. After complementing the limitations of this study, this program can be implemented as an effective means for cooperative learning in the COVID-19 era.

\section{References}

[1] https://www.nocutnews.co.kr/news/5470797, Dec 24 (2020)

[2] http://www.segye.com/newsView/20200310510467, Mar 10 (2020)

[3] https://www.chosun.com/site/data/html_dir/2020/02/27/2020022702963.html, Feb 7 (2020)

[4] https://www.yna.co.kr/view/AKR20200424111100004, Apr 26 (2020)

[5] https://newsis.com/view/?id=NISX20200423_0001004345\&cID=10201\&pID=10200, Apr 23 (2020)

[6] https://www.yna.co.kr/view/AKR20210128067900530, Jan 28 (2021)

[7] https://www.donga.com/news/article/all/20210126/105119963/1, Jan 26 (2021)

[8] D. J. Lee, M. Kim, University students' perceptions on the practices of online learning in the COVID-19 situation and future directions, Multimedia-Assisted Language Learning, (2020), Vol.23, No.3, pp.359-377.

[9] H. Jung, College students' satisfaction with the overall implementation of online classes and testing during the Corona 19 pandemic, Multimedia-Assisted Language Learning, (2020), Vol.23, No.3, pp.392-412. 
[10] https://www.segye.com/newsView/2021012651534, Jan 26 (2021)

[11] http://www.goodnews1.com/news/news_view.asp?seq=102372, Jan 27 (2021)

[12] https://www.news1.kr/articles/?4192964, Jan 26 (2021)

[13] Y. S. Lee, D. K. Shin, An Investigation of the Implementation of Online Classes in the Untact Era Caused by the COVID-19 Pandemic, The Journal of Curriculum and Evaluation, (2020), Vol.23, No.4, pp.39-57.

[14] Y. Koo, S. Lim, K, Kim, Y. Cho, Analysis of user characteristics regarding social network services in South Korea using the multivariate probit model, Technological Forecasting \& Social Change, (2014), Vol.88, pp.232-240, https://doi.org/10.1016/j.techfore.2014.07.001

[15] S. Lee, A Study on Effects of KakaoTalk on English Learning -Focus on Sentence Writing and Learner Satisfaction, THE JOURNAL OF HUMANITIES STUDIES , (2016), Vol.55, N0. 2, pp.249-277, UCI : G704001795.2016.55.2.005

[16] J. Lee, Y. M. Koo, Y. O. Lee, J. K. Kim, J. S. Lim, Teacher and student perspectives on utilization and effectiveness of using social networking service in elementary school, Journal of Korean Association for Educational Information and Media, (2013), Vol.19, No.1, pp.25-54.

[17] A. F. Pearson, Real problems, virtual solutions: Engaging students online. Teaching Sociology, (2010), Vol.38, No.3, pp.207-214, DOI:10.1177/0092055X10370115

[18] E. Y. Kim, J. H. Kim, Y. S. Choi, Effects of reflective activity on learning flow, academic self-efficacy, and academic achievement toward the use of Social Network Services (SNS) on cooperative learning, The Korean Journal of Educational Methodology Studies, (2011), Vol.23, No.4, pp.665-686, DOI : 10.17927/tkjems.2011.23.4.665

[19] Y. B. Oh, A qualitative case study on characteristics of professional development in online teacher community, Journal of Lifelong Learning Society, (2014), Vol.10, No.4, pp.113-137, UCI : G704-SER000015054.2014.10.4.001

[20] M. H. Chung, J. H. Kim, A study on the utilizing SNS as a supplementary learning too, Proceedings of the Korean Association of Computer Education, (2011), Vol.15, No.2, pp.135-138.

[21] J. H. Sung, J. S. Jun, Investigating instructional media attributes of SNS for social learning, Journal of Lifelong Learning, (2012), Vol.18, No.3, pp.31-55, UCI : G704-000781.2012.18.3.00

[22] E. J. Jang, H. J. Jang, Exploration of debate strategies on SNS tools, creativity techniques and group size for Social Network Service (SNS)-based debate, Journal of Korean Association for Educational Information and Media, (2013), Vol.19, No.4, pp.693-721, UCI : G704-000750.2013.19.4.001

[23] H. Cho, G. Gay, B. Davidson, A. Ingraffea, Social networks, communication styles, and learning performance in a CSCL community, Computers, and Education, (2007), Vol.49, No.2, pp.309-329, DOI: https://doi.org/10.1016/j.compedu.2005.07.003

[24] M. S. Kwon, J. S. Kan, J. W. Kim, A study of the educational effects in SNS-utilized instruction, The Journal of Korean Association of Computer Education, (2014), Vol.17, No.6, pp.135-146, http://dx.doi.org/10.32431/kace.2014.17.6.013

[25] J. H. Seung, The effects of the learner's perceived usefulness, attitude and self-efficacy on learning flow and learning presence at university classes using social network service(face book), Educational Technology Graduate School of Konkuk University, Master's Thesis, (2012)

[26] H. R. Lee, B. O. Goh, Development and Application of Web based English Writing System through Cooperative Learning, Korean Society for Information Education, (2011), Vol.15, No.1, pp.137-146, DOI: https://www.earticle.net/Article/A139621

[27] W. S. Suh, W. S. Shin, An analysis of discussion environment and group size in online discussion activities using Social Networking Analysis, Journal of Educational Technology, (2012), Vol.28, No.4, pp.757-779, DOI: 10.17232/KSET.28.4.757

[28] J. Lee, A study of knowledge management strategy using SNS, Proceedings of the Korean Society of Computer Information Conference, (2012), Vol.20, No.1, pp.251-253, UCI : G704-000394.2012.28.4.005

[29] K. Lim, A Case Study on a Learning with Social Network Services on Smartphones: Communication Contents and 
Characteristics Analyses of the Applications. The Korean Journal of Educational Methodology Studies, (2010), Vol.22, No.4, pp.91-114, DOI : 10.17927/tkjems.2010.22.4.91

[30] M. L. Kim, The Cognition of Web-based Cooperative Learning in University Class, Journal of Educational Technology, (2011), Vol.27, No.2, pp.267-287, UCI : G704-000394.2011.27.2.006

[31] M. L. Kim, Cognitive Appraisal and Coping Strategies on Cooperative Learning of Social Network Service, Journal of Korean Association for Educational Information and Media, (2014), Vol.20, No.4, pp.597-620, DOI : 10.15833/KAFEIAM.20.4.597

[32] D. W. Johnson, R. T. Johnson, Learning together and alone: overview and meta-analysis, Asia Pacific Journal of Education, (2002), Vol.22, No.1, pp.95-105, https://doi.org/10.1080/0218879020220110

[33] S. Lee, D. Kim, The effects of collaborative reflection-supporting tools on problem solving performance and process in computer supported collaborative learning environments, Journal of Educational Technology, (2003), Vol.19, No.1, pp.131-159, UCI : G704-000394.2003.19.1.005

[34] S. C. McLoughlin, J. Luca, A learner-centered approach to developing team skills through web-based learning and assessment, British Journal of Educational Technology, (2002), Vol.33, No.5, pp.571-582, DOI:10.1111/14678535.00292

[35] D. L. Jin, A Study on the Development and Application of program utilizing e-Portfolios for The Improvement of selfdirected Learning within Underachieving Undergraduate Students, Majoring in Educational Technology Graduate School of Education, Kyung Hee University, Master's Thesis, (2015)

[36] S. W. Kang, E. K. Lee, N. M. Yang, A study About Developing the Academic Support System Through an Analysis of the Characteristics Between the High Achievers and Underachievers in Their Academic Performance in the University, Korean Journal Of Counseling And Psychotherapy, (2000), Vol.12, No.2, pp.221-242.

[37] S. J. Yune, The Development and Effects of a Preventative Learning Consultation Program for University Underachievers, Journal of Fisheries and Marine Sciences Education, (2013), Vol.25, No.3, pp.643-660, https://doi.org/10.13000/JFMSE.2013.25.3.643

[38] S. H. Lee, Effects of Learning Motive Enhancing Program on Academic Self Efficacy, Learning Habits, and Self Esteem in Underachieve Nursing College Students, Journal of Korean Academic Society for Nursing Education, (2006), Vol.12, No.1, pp.5-12, UCI : G704-001961.2006.12.1.001

[39] M. Balduf, Underachievement Among College Students, Journal of Advanced Academic, (2009), Vol.20, No.2, pp.274-294, https://doi.org/10.1177/1932202X0902000204

[40] H. J. Kwon, The Causes of College Students' Underachievement and Strategies for Improvement, Kangwon National University, Master's Thesis, (2012)

[41] J. Shin, E. H. Chon, Effects of Utilization of Social Network Service on Collaborative Learning, Journal of the Korea Society of Computer and Information, (2013), Vol.18, No.11, pp.241-254, https://doi.org/10.9708/jksci.2013.18.11.241

[42] H. J. Park, An Analysis of the Structural Relationships among Learning Presence, Learning Flow, Learning Satisfaction and Learning Persistence with the Use of SNS in University Classes, Educational Technology Graduate School, KonKuk University, Doctoral Dissertation, (2013)

[43] M. S. Kwon, J. S. Kan, J. W. Kim, A study of the educational effects in SNS-utilized instruction, The Journal of Korean Association of Computer Education, (2014), Vol.17, No.6, pp.135-146, http://dx.doi.org/10.32431/kace.2014.17.6.013 